Cleveland Abbe, for meteorology; Mr. William $\mathrm{H}$. Holmes, for anthropology ; and Mr. S. W. Stratton, for physics.

Owing to the absence of Mr. Rathbun, Dr. Remsen served as chairman at a meeting of the comnittee held at the Smithsonian Institution in Washington, April i 5 . At this meeting, the following resolution was unanimously adopted :-

"That the committee recommend to the secretary of the Smithsonian Institution that it is desirable that one of the Hodgkins gold medals be struck, and that it be

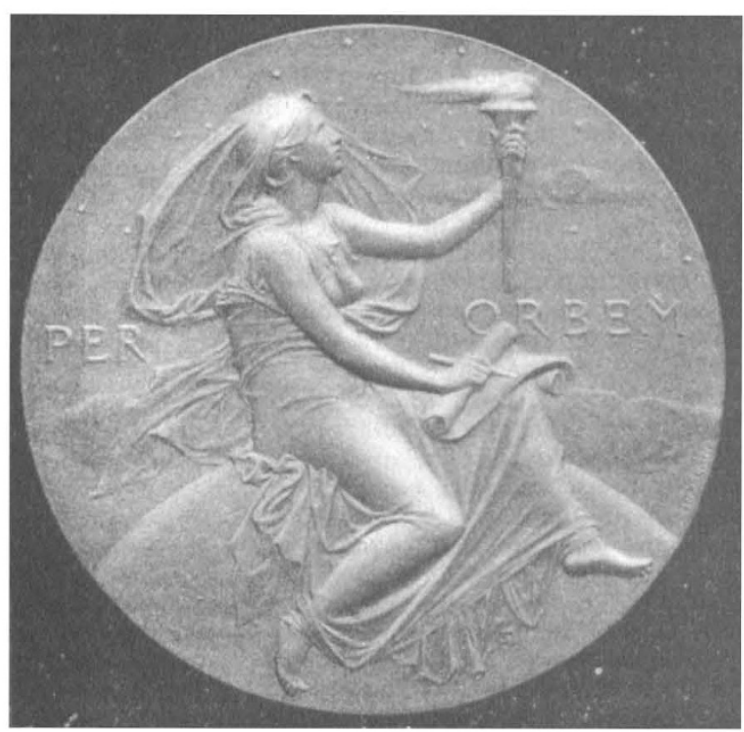

awarded to J. J. Thomson, of Cambridge, England, for his investigations on the conductivity of gases, especially on the gases that compose the atmospheric air."

The finding of the committee being approved by the secretary, steps were at once taken to have the second Hodgkins gold medal struck, under the personal supervision of its designer, M. J. C. Chaplain, of Paris. The medal (one side of which is shown in the accompanying photographic illustration) has recently been received by the Institution, and has been dispatched to Prof. Thomson through the Department of State.

\section{SIR WILLIAM ROBERTS-AUSTEN, K.C.B.,} F.R.S.

$\mathrm{BY}$ the death of Sir William Roberts-Austen, which occurred at his official residence in the Mint on Saturday, November 22, metallurgical science has to deplore the loss of one of its most distinguished repre sentatives. He had been in failing health for some months past, and had suffered from one or two sharp attacks of illness during the last few years, but even his most intimate friends, until a few days before his death, were quite unprepared for the suddenness of his end.

William Chandler Roberts, as he was formerly called, was born in 1843 . His father, (jeorge Roberts, was of Welsh descent, whilst his mother, Maria Louisa, belonged to the Kentish family of Chandler which intermarried with the Austens. In 188;, at the request of his uncle, the late Major Austen, J.P., of Haffenden and Camborne, in Kent, he obtained Royal license to take the name of Austen.

At the age of eighteen, he entered the Royal School of Mines with the intention of being a mining engineer, but after obtaining the associateship of the school he became, in 1865, a private assistant to the late Prof. Graham, then Master of the Mint, and was employed, at the outset, mainly on the researches in inorganic chemistry and on physical chemistry which continued to occupy Graham until the end of his days. Graham died in I 869, when the Department was reorganised in accord ance with the provisions of the Coinage Act of the following year. Under that Act, the Chancellor of the Exchequer became "Master, Worker and Warden" of the Royal Mint. No salary was attached to the office, but it was provided that its duties should "be performed and exercised by his sufficient deputy." In order to provide for the efficient discharge of the scientific work devolving on the Mint, a new post-that of " chemist of the Mint"-was created, and Roberts was selected to fill it, being appointed by Treasury minute of January 7,1870 .

On the death of Mr. Horace Seymour, the late Deputy Master, in June last, Sir Willian Roberts-Austen was appointed to fill the office ad interim, or until his own official connection with the Mint should be severed by resignation. This he had intended should take effect in the spring of the coming year. It may be said, therefore, that Sir William Roberts-Austen had, at one time or other, filled every office in the Mint which a man of his order could aspire to. No more convincing testimony to the manner in which he discharged his official duties, and no more eloquent proof of how he acquitted himself under the great responsibilities of his position, could be adduced than this single fact.

Roberts-Austen was one of the most many-sided men of his time. His intellectual activity found scope for itself in many ways. He had an insatiable capacity for work and he never spared himself. Those who knew him intimately frequently remonstrated with him on the manner in which he incessantly made large drafts on his store of mental and nervous power, with no thought of repose or recuperation. It was rarely that he could be induced to pay much heed to the warnings of his friends, declaring that he found in the very variety of his avocations the relaxation and rest which they desired hım at times to take. This was strikingly exemplified by the manner in which he clung, with an interest amounting to affection, to his position as professor of metallurgy in the Ruyal School of Mines. Roberts-Austen always cherished, as one of the most treasured memories of his life, the recol. lection of his early association with the Royal School of Mines. Although the Royal School of Mines is to-day incorporated with the Royal College of Science, a fusion of which Roberts-Austen entirely approved and which he loyally supported, his colleagues on the council of the school were more or less dimly conscious that deep down in his mind, "at the back of his head," as the saying goes, he was still apt to regard the school as a corporate entity with a separate existence, with all the powers, privileges and prestige which it enjoyed as a separate entity in his old Jermyn Street days. There was probably no one position he coveted more than its chair of metallurgy, and no incident in his career which gave him a greater sense of pleasure and satisfaction than his appointment, in 1880 , to that chair in succession to the late Dr. Percy. The feeling with which he regarded the school is intelligible enough, for it is very human and sprang from his very affection for it. It is akin to that which leads the fond father or doting brother in his secret soul to resent the removal of the daughter or the sister to a new home. No amount of talk about " a larger potentiality for good," "enlarged sphere of activity," "greater measure of advantages," S.c., however willingly and sincerely assented to, will entirely subdue and efface the feeling which in the younger and more militant masculine members of a family has been known to degenerate into a secret wish 
to punch the head of him who has presumed to impose his own name on his partner.

How loyal he was to the school, how affectionately he guarded its interests and how he studied to enhance its usefulness, 1 , who was his colleague on the council of the Royal College of Science for upwards of nine years, desire now to bear testimony. It was the wish of his heart, had he been spared, that, after his retirement from the Mint, he might spend his remaining years, or so many of them as the regulations of the Department would have allowed him to spend, in its service. It was possible that he cherished the hope that the erection of the new buildings on the other side of Exhibition Road might have afforded him the opportunity he had long desired, that of creating and equipping a metallurgical laboratory which should be worthy of this country and of an Empire whose sons are engaged in metallurgical work in almost every part of the globe. But if this was not to be, he has at least erected a monument to himself in the record of his past achievement; in the thoroughness and fulness of his teaching; in the scientific enthusiasm with which he sought to lay bare and illumine the problems of physical metallurgy. During the two-and-twenty years he held his chair, he trained a succession of men holding im. portant positions at home and in many parts of the world, who are grateful to him for the stimulating influence of his teaching, who will recall many acts of personal kindness and good will, and who, now that his place in the sub. terranean lecture-room he loved so well and in which, with all the quickening zeal of a born teacher, he had spent some of the happiest hours of his life, knows him no more, will mourn his loss as that of a dear friend, and will continue to cherish his memory and recall the many kindly traits of head and heart which characterised him.

In the outset of his career as an investigator, Roberts. Austen occupied himself with a number of minor problems in inorganic chemistry, and there is little continuity of thought or effort to be traced in much of his 'prentice work. But there is invariably the note of originality. All his life through, he was strongly attracted by what is odd, uncommon or bizarre. Perhaps it was the Celtic blood which ran in his veins which predisposed him to the mysticism which was undoubtedly a feature of his character. Had he lived three hundred years ago, he would have been a typical alchemist and have spent the skill and energy he showed in assaying and minting gold in vain attempts to make it. Science, how ever, would certainly have been the richer for his efforts, for he was a very acute observer, and although occasion ally his preconceptions were liable to run away with him for a time, especially in the direction of scientific heterodoxy, he was staunchly loyal to his facts. Much of his work was influenced by his strong artistic sense and by his passionate regard for beauty of form or colour. The secrets of oriental metallurgy had a singular fascination for him. He would literally gloat oser some triumph of Japanese art, and the discovery of by what kind of "pickle," or by what kind of treatment, the lustre or colour or effect on a bronze had been obtained was a delight to him as intense as if he had lighted upon a new metal. The artistic side of his nature found frequent exercise in his work at the Mint, especially in medal-striking. He occasionally chafed under the necessity of having to make use of designs for which he had no sympathy, but he had a real delight in reproducing, with the highest degree of excellence that the resources at his command permitted, artistic work which his trained judgment and fine critical insight perceived to be good and true. Indeed, this sense of "finish" and feeling for artistic excellence, amounting almost to fastidiousness, was seen, not only in his actual manipulative work and in the way in which he arranged and perfected his experimental illustration, but in the manner and form in which he put together and presented any account of his labours. His lectures at the Royal Institution were invariably illustrations of this. Perhaps no man since Tyndall's day ever handled a Friday evening discourse with more tact and skill than did Roberts-Austen. HI is matter was always fresh, his experiments always interesting, frequently daring and occasionally strikingly original. He never tried to be rhetorical or pretended to be eloquent, but there was a certain literary finish in his sayings, a feeling for epigraın, a sense of proportion in arrangement, and, at times, a quiet, subdued touch of humour which altogether made him delightful to listen to.

Of his innate love for science and of the ardour with which he pursued her, innumerable instances might be given. I shall never forget the manner in which he burst into my room, when at South Kensington, and showed me the first fragment of the beautiful rosecoloured alloy of gold and aluminium he had obtained. His delight was so real and unaffected-his joy alınost infantile - as he turned and twisted the glittering fragment to the light to illustrate the depth and wonderful brilliancy of its purple. And, too, it was characteristic of him that, as I shared his admiration, he should, unasked, have seized a letter-weight and knocked off a portion of his prize and bade me take it.

I remember, too, a similar occasion when he carried me off to see the first results of his inquiry into the diffusion of solid metals, and when he showed me the little beads of gold cupelled out of the several sections of the block of lead, which had been standing for days and weeks on a plate of the precious metal, all arranged at the proper intervals of the sections on a diagrammatic representation to actual scale of the leaden block. And I may be pardoned if I recall with satisfaction that, as a consequence of that visit, I was the humble instrument of determining, with the powers that were, the Bakerian lecture of 1896 .

The Royal Society's Catalogue of Scientific Papers records that Roberts-Austen published some two dozen papers, for the most part singly, but occasionally in collaboration with Sir Norman Lockyer, Prof. Qsmond and the late Dr. Alder Wright.

They practically all relate to metallurgical problems, or are connected with the scientific side of his duties as an officer of the Mint. They deal with the spectroscopic characters of alloys ; the physical and chemical nature of alloys; the structure of metals ; the connection between the-properties of metals and the periodic law ; and the nature of the hydrogen occluded by palladium and by electro-deposited iron.

In 1890 , at the request of the Alloys Research Committee of the Institution of Mechanical Engineers, he began to investigate the effects of small admixture of certain elements on the mechanical and physical properties of the common metals and their alloys. Whilst engaged on that work, he devised the recording pyrometer, an instrument which has proved to be of the greatest value, not only to the investigator in pure science, but also to the practical metallurgist. The results of these investigations are embodied in reports to the Institution of Mechanical Engineers, which afford a mass of valuable information concerning the structure of metals and their alloys, and their behaviour under varying physical conditions.

It was in the domain of physical metallurgy that he specially excelled, and by his unwearied energy, by his skill and resourcefulness as an experimentalist, he has succeeded in clearing up much that was vague and imperfectly understood in that field of inquiry.

$\mathrm{He}$ is the author of an "Introduction to the Study of Metallurgy," which has been characterised as a masterly guide to a knowledge of the principles on which the art is based.

NO. I 727 , VOL. 67$]$ 
This bald outline of Roberts-Austen's scientific work gives, however, a very inadequate idea of his diligence as a man of science or of the influence which he exerted on the progress of science. Such work as he engaged in was, from its very nature, time-consuming, and results иere only obtained slowly and laboriously. From his official position, too, and by reason of his attainments, he was constantly pressed to serve upon committees, councils and commissions, into the work of which he never failed to throw himself with characteristic ardour and self-sacrifice. In 1885 , he was a member of the executive council of the Inventions Exhibition. In 1889 , he served on the British executive council of the Paris Exhibition, and in 1893 on that of the Chicago Exhibition. In the former year, he received the Cross of Chevalier of the Legion of Honour.

He sat with the writer on the Treasury Committee which preceded the establishment of the National Physical Laboratory, and he was also a member of the Board of Trade Committee appointed to inquire into the deterioration of steel rails during use in railway traction.

Since 1899, he had been a member of the Explosives Committee appointed to investigate explosives for use in the Army and Navy and material for the construction of guns.

Concurrently with the services he rendered to the State as a public servant, he did his fair share of labour in the organisation of scientific work as an executive officer of various scientific societies. He joined the Chemical Society in 1866 and served on its council in $1879-81$, and became a vice-president in $1895-8$.

In 1875 he was elected into the Royal Society, and served as a member of council in 1890-2, and at the time of his death was a member and chairman of some of its committees. He was one of the founders of the Physical Society, of which he was also a vice-president and was an active member of the Society of Arts, of which he was a member of council and vice-president. $\mathrm{He}$ was also an honorary member of the Institution of Civil Engineers, of the Institution of Mechanical Engineers and of the Institution of Mining and Metallurgy.

He was elected president of the Iron and Steel Institute in 1899 , and held office until 1901 .

In 1888 he was made a C. B., and received his knighthood in the order in 1899 .

The University of Durham made him a D.C.L. in 1897 , and a year or two later he received the honorary degree of D.Sc. from the Victoria University.

He was a frequent attendant of the meetings of the British Association, and served as one of the general secretaries of the council from 1897 to the year of his death.

His last public lecture was the James Forrest lecture on "Metallurgy in Relation to Engineering," given to the Institution of Civil Engineers on April 23. In special lectures of this kind, Roberts-Aust en excelled. They cost him considerable effort, for he spared no trouble to make the occasion worthy of himself and of his subject, and he had his reward in the grateful appreciation of his auditory.

Indeed, no man discharged more faithfully, more honourably or more religiously the obligations he had incurred, or which, by virtue of his position, were thrust upon him. It may be truthfully said of him that whatsoever his hand found to do he did it with all his might.

No sketch of Roberts-Austen would be complete without some allusion to his remarkable social qualities. When at his best he was an admirable talker, bright, witty and amusing; he had a keen sense of humour and was a capital story-teller. He had a dangerous gift, however, which in his later years he was slow to make use of-he was an excellent mimic. In the old days--

$$
\text { No. } 1727 \text {, VOL. } 67 \text { ? }
$$

the days of Rankine, Lord Houghton, Clifford, Aitchison -when the "Red Lions" were wont to hold high carnival, Roberts-Austen occasionally would "let himself go" and exercise his gift to the uproarious merriment of jackals, cubs, lions and lion-kings alike. Indeed, it seemed at times that he was not quite conscious of the faculty he possessed. I have heard him, to my terror, in the course of a conversation gradually copy the tones and inflexions of a man's voice, and seen him reproduce his manner to his very face. There was absolutely no intention to be discourteous in this, and it was done so gradually and with such subtlety that the man was just as insensible of the fact as Roberts himself. I firmly believe that on such occasions the unconscious mimicry had its origin in sympathy.

Some years ago, Roberts-Austen acquired a small place at Chilworth, near Guildford, to which he would repair with Lady Roberts-Austen on all possible occasions. It never meant idleness to him, but there is no doubt that the occasional change from the atmosphere of Tower Hill to the breezy, invigorating air of a Surrey common had some effect in preserving him from the constant inroad he made upon his physical and mental energy. His social instincts made him a good neighbour, and he spent time and no inconsiderable amount of money in improving the lot of those around him. There was one side of his character of which only those who knew him well were made fully aware. It is reflected, however, in the beautifully decorated little chapel which he erected near his house for the benefit of the district, and in which he was wont to minister nearly every Sunday.

T. E. THORPE.

\section{ANNIVERSARY MEETING OF THE ROYAL SOCIETY.}

THE anniversary meeting of the Royal Society was held on Monday, December 1, when the report of the Council was presented, and the members of the Council for the ensuing year, whose names have already been given (p. 35), were elected.

The first paragraph of the report refers to the formation of the "British Academy for the Promotion of Historical, Philosophical and Philological Studies" and its incorporation by Royal Charter. The President and Council of the Society were requested by the Privy Council to give their opinion upon a petition which had been presented to the Privy Council praying that the incorporation of the studies above referred to should be "provided for in some relation to the Royal Society." The report states that in the reply the Council of the Royal Society most strongly deprecated any change in organisation being imposed upon the Society from without in order that it might include within itself the studies for which the incorporation of the British Academy is asked, being convinced that such a change would destroy the independent position which the Society now enjoys as the head, in this country, of the mathematical, experimental and natural sciences. The Privy Council subsequently invited the opinion of the Royal Society upon a memorial suggesting that it would be desirable to attempt to organise officially in one institution the several branches of knowledge. The President and Council replied that they could not consent to the Royal Society forming one department of any institution or academy such as that suggested.

The statutes governing the election of Fellows under privileged conditions, under which nembers of the Privy Council have hitherto been admitted, have been amended. The principal amendment provides that the Council may, once in every two years, recommend to the 